Article

\title{
Signal Grass Deferred Pastures Fertilized with Nitrogen or Intercropped with Calopo
}

\author{
Carla Silva Chaves ${ }^{1}$, Karina Guimarães Ribeiro ${ }^{1, *}$, Odilon Gomes Pereira ${ }^{1}\left(\mathbb{D}\right.$, Dilermando Miranda da Fonseca ${ }^{1}$, \\ Paulo Roberto Cecon ${ }^{2}$ (D) and Carlos Augusto de Miranda Gomide ${ }^{3}$ \\ 1 Department of Animal Science, Universidade Federal de Viçosa, Viçosa 36570-900, Brazil \\ carlazootecnia@gmail.com (C.S.C.); odilon@ufv.br (O.G.P.); dfonseca@ufv.br (D.M.d.F.) \\ 2 Department of Statistics, Universidade Federal de Viçosa, Viçosa 36570-900, Brazil; cecon@ufv.br \\ 3 National Dairy Cattle Research, EMBRAPA, Juiz de Fora 36038-330, Brazil; carlos.gomide@embrapa.br \\ * Correspondence: karinaribeiro@ufv.br; Tel.: +55-11-31-3612-4950
}

check for updates

Citation: Chaves, C.S.; Ribeiro, K.G.; Pereira, O.G.; da Fonseca, D.M.; Cecon, P.R.; Gomide, C.A.d.M. Signal Grass Deferred Pastures Fertilized with Nitrogen or Intercropped with Calopo. Agriculture 2021, 11, 804. https://doi.org/10.3390/agriculture 11090804

Academic Editors: Stefano Tavoletti, Martin Weih and M. Inés Mínguez

Received: 5 July 2021

Accepted: 20 August 2021

Published: 24 August 2021

Publisher's Note: MDPI stays neutral with regard to jurisdictional claims in published maps and institutional affiliations.

Copyright: (c) 2021 by the authors. Licensee MDPI, Basel, Switzerland. This article is an open access article distributed under the terms and conditions of the Creative Commons Attribution (CC BY) license (https:// creativecommons.org/licenses/by/ $4.0 /)$.

\begin{abstract}
This study aimed to evaluate the accumulation, structural characteristics, and chemical composition of deferred signal-grass pastures that were subjected to four treatments: without nitrogen fertilization, intercropped with calopo (Calopogonium mucunoides), and fertilized with urea $\mathrm{N}$ (50 kg ha ${ }^{-1}$ and $100 \mathrm{~kg} \mathrm{ha}^{-1}$ ) for 2 years. The design was in randomized blocks, with two blocks and two repetitions of each treatment per block. There were effects of the interaction between treatment and year on green dry mass, forage accumulation, density of vegetative tillers, and crude protein content (simulated grazing). The effects of the treatments on the height, falling index, green dry mass/dead dry mass ratio, number of dead, live and total tillers, and crude protein content (direct cutting) were also observed. Signal-grass-calopo-intercropping ensured adequate mass and forage accumulation and crude protein content equivalent to those of fertilized pastures. In addition, the intercropped pasture showed a higher percentage of leaves and a higher crude protein content compared with those for the other treatments (simulated grazing). The green dry mass/dead dry mass ratio was highest in the intercropped pasture and was equivalent to only that of the pasture fertilized with a low dose of nitrogen. Therefore, signal-grass-calopo-intercropping may be recommended for deferment.
\end{abstract}

Keywords: chemical composition; falling index; forage accumulation; morphological characteristics; structural characteristics

\section{Introduction}

Seasonal variations have a significant impact on forage production, especially during dry periods, in tropical regions and when climatic limitations compromise the development and chemical composition of pastures and affect animal performance. Deferment is an option to minimize this problem and consists of postponing or delaying grazing to achieve a specific management objective [1]. The proper choice of plant species to be used in the deferment is essential, and characteristics, such as good growth potential in the beginning of autumn and a high leaf/stem ratio, are sought after to provide improved nutritional value to the accumulated forage. Therefore, species of the genus Urochloa have been recommended for deferment [2,3].

Deferment management strategies can influence the forage mass, chemical composition, and structural characteristics of pastures, which affects animal production [3-5]. Nitrogen fertilization before pasture deferment can improve the forage mass and its chemical composition. In a study of deferred signal grass [5], the authors observed an increase in forage mass and an improvement in structural characteristics as the nitrogen dose increased, while increases in mass and allowance forage were identified [6]. However, nitrogen fertilization considerably increases the costs of production, as the synthesis of fertilizers requires sources of fossil fuel, and most nitrogen inputs are currently imported [7]. 
Therefore, nitrogen from biological fixation by legumes constitutes an important contribution to agricultural and pasture systems, as it benefits the environment and supports resource efficiency, although it becomes available slowly [8,9].

Among many legumes used in intercropping systems, calopo (Calopogonium mucunoides Desv.) stands out because of its ability to adapt to conditions of high acidity and low soil fertility, in addition to its high tolerance to $\mathrm{Al}$ [10]. In reference [11], the researchers observed that calopo intercropped with Urochloa decumbens cv. Basilisk (Stapf) R.D. Webster) recycles $84 \mathrm{~kg} \mathrm{ha}^{-1}$ year $^{-1}$ of $\mathrm{N}$ during continuous stocking in the rainy season, resulting in increased nitrogen availability for grasses and crude protein $(\mathrm{CP})$ content in forage.

The use of a nitrogen fertilizer has been evaluated in several deferment studies; however, studies with grass-legume-intercropping systems under deferment are not available. Therefore, the aim of this study was to evaluate the total mass, accumulation, structural characteristics, and chemical composition of signal-grass pastures under deferment, intercropping with calopo or fertilization with nitrogen for two years. We hypothesized that signal grass-calopo intercropping or signal-grass pastures fertilized with nitrogen under deferment would result in the improved mass, accumulation, structural characteristics, and chemical composition of forage during the dry season.

\section{Materials and Methods}

\subsection{Experimental Site}

The experiment was conducted in 2017 and 2018 at the Teaching, Research, and Extension Unit of the Animal Science Department of the Universidade Federal de Viçosa (UFV), located in Viçosa, Minas Gerais State, Brazil (20 $45^{\prime \prime}$ S, 52 $55^{\prime \prime}$ W; elevation of $649 \mathrm{~m}$ a.s.l.). Accumulated precipitation and average temperature data during the experimental period were obtained from the Viçosa Meteorological Station and were $846 \mathrm{~mm}$ and $21.8^{\circ} \mathrm{C}$, respectively, in 2017 and $1133 \mathrm{~mm}$ and $22.2^{\circ} \mathrm{C}$, respectively, in 2018 (Figure 1).

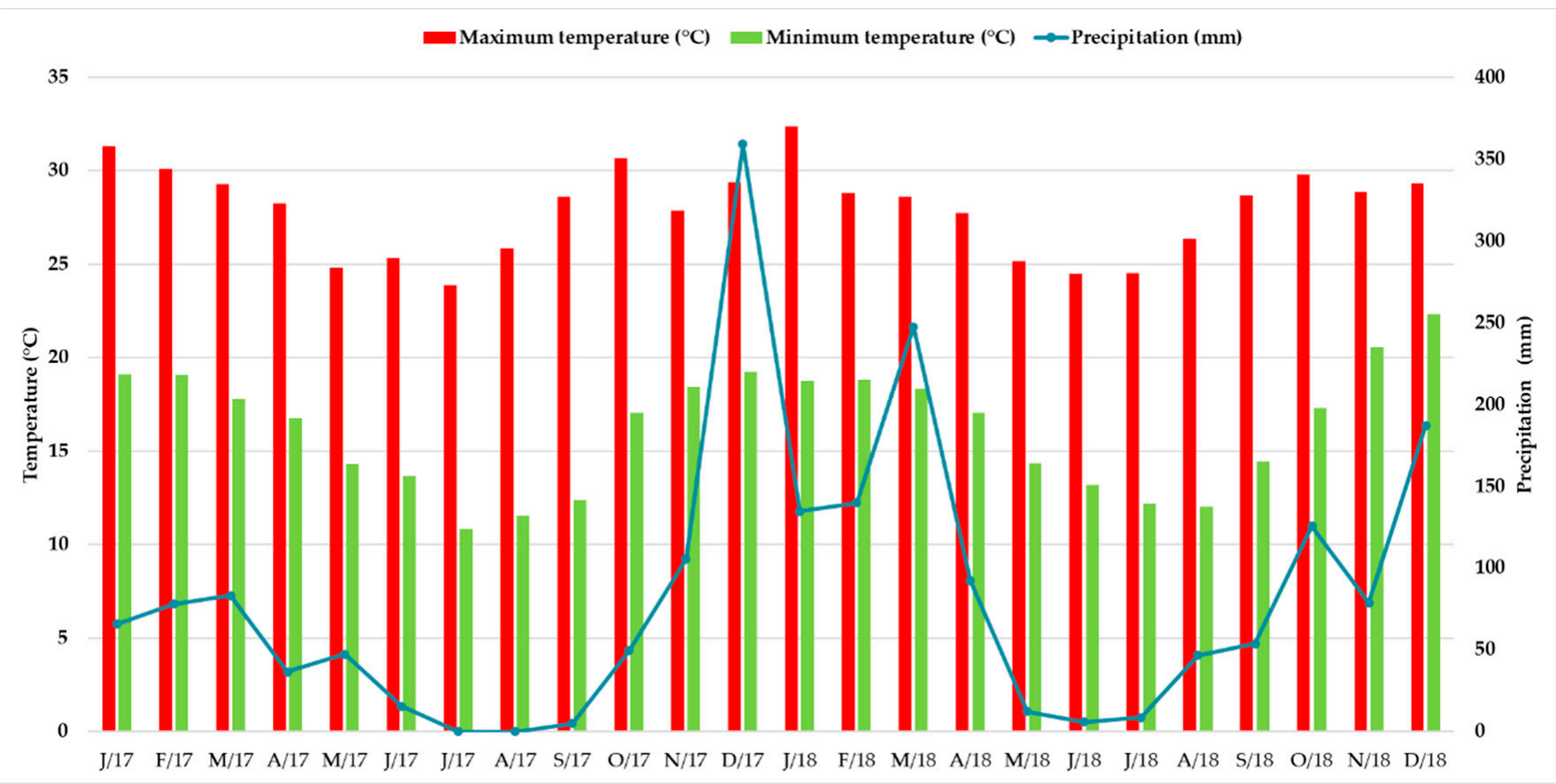

Figure 1. Weather data from January (J) 2017 to December (D) 2018, in Viçosa, Minas Gerais, Brazil. Source: INMET, 2019.

The soil was classified as red-yellow dystrophic latosol [12]. Soil samples were collected with a probe from 0 to $10 \mathrm{~cm}$ layers in August 2016, and the chemical composition was analyzed (Table 1). Given the results, soil fertilization was carried out following the recommendations of [13]. There was no need for soil correction or potassium fertilization. 
In January 2017, $70 \mathrm{~kg} \mathrm{ha}^{-1} \mathrm{P}_{2} \mathrm{O}_{5}$ was applied to all paddocks using simple superphosphate as the source.

Table 1. Chemical analysis of soil samples collected in the $0-10 \mathrm{~cm}$ layers in the experimental area.

\begin{tabular}{|c|c|c|c|c|c|c|c|c|c|c|c|c|c|}
\hline $\mathrm{pH}$ & $\mathbf{P}$ & $\mathbf{K}$ & $\mathrm{Ca}^{2+}$ & $\mathrm{Mg}^{2+}$ & $\mathrm{Al}^{3+}$ & $\mathbf{H}+\mathbf{A l}$ & EB & $(t)$ & (T) & $\mathbf{V}$ & $\mathbf{m}$ & OM & P-rem \\
\hline $\mathrm{H}_{2} \mathrm{O}$ & \multicolumn{3}{|c|}{$\mathrm{mg} \mathrm{dm}^{-3}$} & \multicolumn{6}{|c|}{$\mathrm{cmol}_{\mathrm{c}} \mathrm{dm}^{-3}$} & \multicolumn{2}{|c|}{$\%$} & dag $\mathrm{kg}^{-1}$ & $\mathrm{mg} \mathrm{L}^{-1}$ \\
\hline 5.51 & 7.4 & 177 & 2.61 & 0.99 & 0.1 & 6.9 & 4.05 & 4.15 & 10.95 & 37 & 2.4 & 3.33 & 29.6 \\
\hline
\end{tabular}

Abbreviations: $\mathrm{pH}$, in water, 1:2.5; EB, sum of exchangeable bases; $t$, capacity of effective cation exchange; $\mathrm{T}$, cation exchange capacity at $\mathrm{pH}$ 7.0; $\mathrm{V}$, base saturation index; $\mathrm{m}$, aluminum saturation; OM, organic matter; P-rem, remaining phosphorus.

The experiment was conducted in a signal-grass pasture containing 16 paddocks $\left(\sim 1300 \mathrm{~m}^{2}\right.$ each) with a water trough and a mineral mixture feeder in each paddock. The pastures were established $\sim 23$ years ago and have been properly managed and fertilized for other studies. At the beginning of this experiment, the signal grass had good soil coverage.

In January 2017, $50 \mathrm{~cm}$ spaced lines of signal grass were desiccated with glyphosate ( $200 \mathrm{~mL} / 20 \mathrm{~L}$ water) using a costal pump in the pastures, in which calopo was sown. After desiccating the signal grass, the calopo was sown by animal traction using a seeder with cutting discs at a sowing rate of $4.8 \mathrm{~kg} \mathrm{ha}^{-1}$ of viable pure seeds. In December 2017, due to the low density of the calopo plants, reseeding was carried out by direct broadcasting at the same sowing rate. Before reseeding, the pasture height was lowered by cow grazing, and the animals were again introduced into the paddocks for a few hours after reseeding to promote the contact between the seeds and soil.

\subsection{Treatments and Experimental Design}

Deferred signal-grass pastures were subjected to the following treatments: B (without nitrogen fertilization as a control), BC (intercropped with calopo), B50 (fertilized with a low dose of nitrogen of $50 \mathrm{~kg} \mathrm{ha}^{-1}$ ), or B100 (fertilized with a high dose of nitrogen of $100 \mathrm{~kg} \mathrm{ha}^{-1}$ ). The experiment was carried out under a two-way factorial assay in a randomized complete block design. The four treatments were distributed in two randomized blocks with two repetitions of the treatment per block in two experimental years (2017 and 2018).

\subsection{Grazing Management}

During the predeferral periods, grazing with Nellore heifers was carried out under intermittent stocking conditions with variable stocking rates. The pre- and postgrazing heights were $25 \mathrm{~cm}$ and $15 \mathrm{~cm}$, respectively, in both experimental years. The pastures were deferred on 7 March in 2017 and 2018 and remained closed to grazing (without animals) until 13 June 2017 and until 15 May 2018, respectively, when the animals returned to the paddocks. In 2017 and 2018, the deferral periods for the pastures were 98 days and 70 days, respectively, and the periods during which the animals remained grazing after the deferral period were 58 days and 43 days, respectively. The protocol for the research project has been approved by the Ethics Commission on the use of farm animals of UFV (protocol no. 020/2018).

\subsection{Mass, Forage Accumulation Rate (FAR), and Structural Characteristics and Chemical Composition of Pastures}

Prior to the start of the deferral period, the postgrazing residue heights were measured at 20 points per experimental unit with a graduated ruler, and four samples of forage were collected ( $2 \mathrm{~cm}$ above the ground level) at random in each paddock using frames $(0.50 \mathrm{~m} \times 0.50 \mathrm{~m})$. Subsequently, nitrogen fertilization was carried out in the experimental units that received these treatments, and the pastures of some paddocks were fertilized with nitrogen doses of $50 \mathrm{~kg} \mathrm{ha}^{-1}$ (low dose) and $100 \mathrm{~kg} \mathrm{ha}^{-1}$ (high dose) using urea as a source. 
The forage samples were taken to the laboratory where they were weighed and separated into a green material $(\mathrm{G})$ and a senescent and dead material (DE), separately weighed and dried in an oven with forced air circulation at $55^{\circ} \mathrm{C}$ until reaching a constant mass. Subsequently, the samples were ground in a knife mill with a $1 \mathrm{~mm}$ sieve, and subsamples were dried in an oven at $105^{\circ} \mathrm{C}$ to determine the dry matter (method 930.15; [14]). In addition, analyses of the $\mathrm{CP}$ content (method 990.03; [14]) and the insoluble neutral detergent fiber corrected for ash and protein (NDFap) contents $[15,16]$ were performed.

The falling index (FI) was obtained by dividing the extended tiller height (ETH) by sward height (SH), according to the methodology proposed by [17]. Four samples of forage were also collected ( $2 \mathrm{~cm}$ above the ground) at random in each paddock using a frame $(0.5 \mathrm{~m} \times 0.5 \mathrm{~m})$ to quantify the total population density of tillers. Live tillers (LTs) with inflorescences were classified as reproductive (RT), whereas LTs without inflorescences were classified as vegetative (VT) and those of which the stems were necrotic were classified as dead tillers (DTs). The sum of the number of vegetative and reproductive tillers (tillers $/ \mathrm{m}^{2}$ ) corresponded to LTs, and that of LTs and DTs corresponded to total tillers (TTs).

After counting the tillers, each sample was weighed and divided into two subsamples. The first subsample was separated into green leaf blades (L), green stems (S), and DEs. The $\mathrm{L}$ and $\mathrm{S}$ portions with either yellowing or necrotizing characteristics were incorporated into the DE fraction. After separation, the components were weighed and dried in an oven with forced air circulation, the samples were ground, and the subsamples were dried in an oven to determine the dry matter content (method 930.15; [14]). From these data, leaf dry mass (LDM), stem dry mass (SDM), dead dry mass (DEM), green dry mass (GDM), and total dry mass (TDM) were obtained, in addition to the relative proportion (\%) of each morphological component in the available forage. The GDM/DEM and L/S ratios were also estimated. The second subsample was subsequently analyzed for chemical composition, as previously described.

Forage accumulation (FA) was calculated as the difference between the forage mass harvested after pasture deferment and the forage mass before deferment for each experimental year. The FAR was estimated as the ratio between the FA and the number of days of deferment for each experimental year.

On the first, second, and third days of grazing, forage samples were collected in each paddock, simulating the forage that was removed by heifers, according to the methodology described by [18]. Each sample was separated into the L, S, and DE components and subsequently dried and weighed according to the same previously described criteria. Subsequently, all morphological components were joined together to recompose their original samples, which were analyzed for chemical composition, as previously described.

\subsection{Statistical Analysis}

For each characteristic, an analysis of variance (ANOVA) was performed under a two-way factorial assay in a randomized complete block design. The treatments $(\mathrm{B}, \mathrm{BC}$, B50, and B100) and the experimental year (2017 and 2018), as well as their interaction, were tested as fixed effects. The analysis of the experimental data was performed using the System for Statistical Analysis software (SAEG v. 8.1; [19]). The ANOVA assumptions given by the normality of residuals and homogeneity of variances were evaluated using the Shapiro-Wilk and O'Neill-Matthews tests, respectively. The comparisons between the means of treatments were performed through the Tukey's test, considering a 5\% probability of type I error.

\section{Results}

The SH was affected $(p=0.0043)$ by treatment (Table 2$)$ and by experimental year $(p=0.0031)$, and the SH was greater in $2018(58.8 \mathrm{~cm})$ than in $2017(50.6 \mathrm{~cm})$. The BC treatment showed a higher SH than treatment $\mathrm{B}$, whereas the other treatments presented intermediate values. The highest $(p=0.0241)$ FI was also observed in the intercropped 
pasture compared with that of the signal-grass pasture without a nitrogen fertilizer, with intermediate values in the other treatments (Table 2).

Table 2. Averages of sward heights (SHs) and falling indices (FIs) for the different treatments at the end of the deferral period.

\begin{tabular}{ccc}
\hline Treatment & SH $(\mathbf{c m})$ & FI \\
\hline B & $47.6 \mathrm{~B}$ & $1.5 \mathrm{~B}$ \\
BC & $62.1 \mathrm{~A}$ & $2.0 \mathrm{~A}$ \\
B50 & $55.1 \mathrm{AB}$ & $1.8 \mathrm{AB}$ \\
B100 & $53.9 \mathrm{AB}$ & $1.9 \mathrm{AB}$ \\
Mean standard error & 1.63 & 0.007
\end{tabular}

Means followed by at least the same letters in the column do not differ at the level of a 5\% probability by the Tukey's test. Abbreviations: B, signal grass which was not fertilized with nitrogen (control); BC, signal grass intercropped with calopo; B50, signal grass fertilized with a dose of $50 \mathrm{~kg} \mathrm{ha}^{-1} \mathrm{~N}$; B100, signal grass fertilized with a dose of $100 \mathrm{~kg} \mathrm{ha}^{-1} \mathrm{~N}$.

The LDM did not differ $(p=0.7358)$ between treatments and experimental years, with an average of $833.52 \mathrm{~kg} \mathrm{ha}^{-1}$. On the other hand, the TDM was influenced by the experimental year $(p=0.0220)$, with a higher value detected in $2018\left(6622.2 \mathrm{~kg} \mathrm{ha}^{-1}\right)$ than in 2017 (5688.9 $\left.\mathrm{kg} \mathrm{ha}^{-1}\right)$. In addition, the GDM was influenced by the interaction between treatment and experimental year ( $p=0.0307$; Table 3). In 2017, the GDM was higher for the BC treatment than for the B treatment. However, in 2018, there was no difference in GDM between treatments. When comparing years within each treatment, there was an increase in GDM from 2017 to 2018 for the B100 and B (control) treatments, while the GDM decreased for the BC treatment and remained constant for the B50 treatment.

Table 3. Averages of green dry mass (GDM), stem dry mass (SDM), and forage accumulation (FA) for the different treatments and experimental years at the end of the deferral period.

\begin{tabular}{|c|c|c|c|}
\hline Treatment & 2017 & 2018 & Mean Standard Error \\
\hline \multicolumn{4}{|c|}{ GDM (kg ha-1 DM) } \\
\hline B & $3140.6 \mathrm{Bb}$ & $4625.5 \mathrm{Aa}$ & \multirow{4}{*}{202.02} \\
\hline $\mathrm{BC}$ & $5110.4 \mathrm{Aa}$ & $3793.8 \mathrm{Ab}$ & \\
\hline B50 & 4253.9ABa & $5068.2 \mathrm{Aa}$ & \\
\hline B100 & $3593.8 \mathrm{ABb}$ & 5204.9Aa & \\
\hline \multicolumn{4}{|c|}{$\operatorname{SDM}\left(\mathrm{kg} \mathrm{ha}^{-1} \mathrm{DM}\right)$} \\
\hline $\mathrm{B}$ & $884.3 \mathrm{Ba}$ & 1346.6Aa & \multirow{4}{*}{201.30} \\
\hline $\mathrm{BC}$ & 1673.0Aa & $1169.9 \mathrm{Ab}$ & \\
\hline B50 & $1332.3 \mathrm{ABa}$ & 1444.1Aa & \\
\hline B100 & $1072.5 \mathrm{ABb}$ & 1584.7Aa & \\
\hline \multicolumn{4}{|c|}{ FA $\left(\mathrm{kg} \mathrm{ha}^{-1} \mathrm{DM}\right)$} \\
\hline B & $1592.6 \mathrm{Bb}$ & 3556.3Aa & \multirow{4}{*}{246.45} \\
\hline $\mathrm{BC}$ & 3992.6Aa & $1861.2 \mathrm{Ab}$ & \\
\hline B50 & 2919.1ABa & 3858.7Aa & \\
\hline B100 & $2279.8 \mathrm{AB}$ & 3164.3Aa & \\
\hline
\end{tabular}

Means followed by at least one capital letter in the column and lower case in the line do not differ at the level of $5 \%$ probability by the Tukey's test. Abbreviations: B, signal grass which was not fertilized with nitrogen (control); $B C$, signal grass intercropped with calopo; B50, signal grass fertilized with a dose of $50 \mathrm{~kg} \mathrm{ha}^{-1} \mathrm{~N}$; B100, signal grass fertilized with a dose of $100 \mathrm{~kg} \mathrm{ha}^{-1} \mathrm{~N}$.

Furthermore, the SDM was also affected $(p=0.0703)$ by the interaction between treatment and experimental year (Table 3). In 2017, the BC treatment had a higher SDM than the pasture without nitrogen fertilization (B), with intermediate values for the B50 and B100 treatments. However, in 2018, there was no difference in this variable among treatments. When we compared the experimental year within each treatment, it was observed that the SDM decreased from 2017 to 2018 for the BC treatment; however, the SDM increased during the same period for the B100 treatment. 
The FA was also influenced $(p=0.0156)$ by the interaction between treatment and experimental year (Table 3). In 2017, there was a greater accumulation of forage for the BC treatment than for the B treatment. In contrast, in 2018, this variable showed similar values among treatments. When comparing years within each treatment, an increase in FA was observed from 2017 to 2018 for the B treatment, while the FA decreased for the BC treatment and remained unchanged in both years for the other two treatments. The FAR was affected only by experimental year $(p=0.0001)$, with higher values in 2018 than in 2017 (50.6 kg ha ${ }^{-1}$ day $^{-1}$ DM vs. $27.5 \mathrm{~kg} \mathrm{ha}^{-1}$ day $^{-1} \mathrm{DM}$; mean standard error, SE = 3.19).

Although the DEM was affected $(p=0.0035)$ by all treatments, it was noted that the intercropped pasture had lower DEM values than those of the other treatments (Table 4). There was also an effect ( $p=0.0137)$ of treatment on the GDM/DEM ratio, which was higher for the BC treatment than for the B and B100 treatments (Table 4).

Table 4. Averages of dead dry mass (DEM), the green dry mass/dead dry mass ratio (GDM/DEM), and percentages of stem $(\% \mathrm{~S})$ and dead material $(\% \mathrm{DE})$ for the different treatments at the end of the deferral.

\begin{tabular}{ccccc}
\hline Treatment & $\begin{array}{c}\text { DEM } \\
\left(\mathbf{k g ~ h a}^{\mathbf{- 1}} \mathbf{D M}\right)\end{array}$ & GDM/DEM & $\begin{array}{c}\text { Percentages of } \\
\text { Stem } \mathbf{( \% \mathbf { ~ } )}\end{array}$ & $\begin{array}{c}\text { Percentages of } \\
\text { Dead Material } \\
\text { (\%DE) }\end{array}$ \\
\hline B & $999.5 \mathrm{~A}$ & $4.1 \mathrm{~B}$ & $37.9 \mathrm{~B}$ & $34.9 \mathrm{~A}$ \\
BC & $517.6 \mathrm{~B}$ & $9.3 \mathrm{~A}$ & $50.9 \mathrm{~A}$ & $20.4 \mathrm{~B}$ \\
B50 & $904.2 \mathrm{~A}$ & $5.6 \mathrm{AB}$ & $43.8 \mathrm{AB}$ & $28.8 \mathrm{AB}$ \\
B100 & $978.5 \mathrm{~A}$ & $5.2 \mathrm{~B}$ & $40.6 \mathrm{~B}$ & $31.2 \mathrm{~A}$ \\
Mean standard error & 91.2 & 1.1 & 1.43 & 1.62 \\
\hline
\end{tabular}

Means followed by at least the same letters in the column do not differ at the level of a $5 \%$ probability by the Tukey's test. Abbreviations: B, signal grass which was not fertilized with nitrogen (control); BC, signal grass intercropped with calopo; B50, signal grass fertilized with a dose of $50 \mathrm{~kg} \mathrm{ha}^{-1} \mathrm{~N}$; B100, signal grass fertilized with a dose of $100 \mathrm{~kg} \mathrm{ha}^{-1} \mathrm{~N}$.

The L percentage ( $p=0.9187)$ and the $\mathrm{L} / \mathrm{S}$ ratio $(p=0.2091)$ values were not affected by either treatment or experimental year, with averages of $27.85 \%$ and 0.66 , respectively. The $S$ percentage $(p=0.0044)$ and the DE $(p=0.0075)$ content were affected by treatment (Table 4 ). The BC treatment had a higher S percentage and lower DE values than the B and B100 treatments.

The number of RTs was not affected $(p=0.1983)$ by the factors studied, with an average of 292 tillers $/ \mathrm{m}^{2}$. The number of VTs was affected $(p=0.0137)$ by the interaction between treatment and experimental year (Table 5). When comparing the treatments within each year, it was noted that in 2017 , the highest dose of the nitrogen fertilizer contributed to a greater number of VTs compared with that of the intercropped pasture. However, in 2018, all the other treatments provided higher numbers of VTs than those of the intercropped pasture. Moreover, when comparing years within each treatment, it was observed that the number of VTs increased from 2017 to 2018 for only the B and B50 treatments.

Table 5. Averages of the number of vegetative tillers (VTs) for different treatments and experimental years at the end of the deferral period.

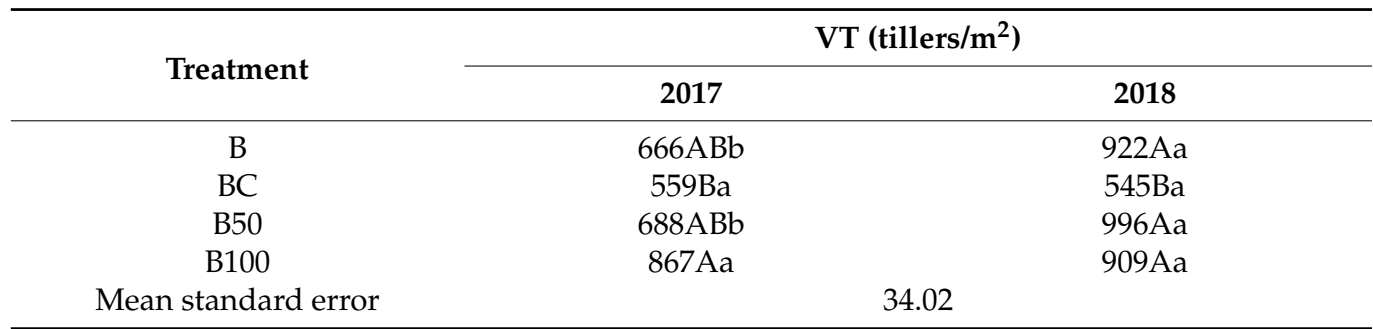

Means followed by at least one capital letter in the column and lower case in the line, for each variable, do not differ at the level of a 5\% probability by the Tukey's test. Abbreviations: B, signal grass which was not fertilized with nitrogen (control); BC, signal grass intercropped with calopo; B50, signal grass fertilized with a dose of $50 \mathrm{~kg} \mathrm{ha}^{-1} \mathrm{~N}$; B100, signal grass fertilized with a dose of $100 \mathrm{~kg} \mathrm{ha}^{-1} \mathrm{~N}$. 
The numbers of DTs $(p=0.0247)$, LTs $(p=0.0001)$, and TTs $(p=0.0001)$ were affected by treatment (Table 6). The number of DTs was lower for the BC treatment than for the B and B100 treatments. However, the numbers of LTs and TTs were lower for the BC treatment than for the other treatments. The number of DTs was also affected $(p=0.0465)$ by experimental year, with a higher value observed in 2018 (355 tillers $\left./ \mathrm{m}^{2}\right)$ than in 2017 $\left(238\right.$ tillers $\left./ \mathrm{m}^{2}\right)$. However, the values of LTs $(p=0.2972)$ and TTs $(p=0.4230)$ were not affected by experimental year, with average values of $1035 \mathrm{LT} / \mathrm{m}^{2}$ and $1088 \mathrm{LT} / \mathrm{m}^{2}$ in 2017 and 2018, respectively, and $1327 \mathrm{TT} / \mathrm{m}^{2}$ and $1390 \mathrm{TT} / \mathrm{m}^{2}$ in 2017 and 2018, respectively.

Table 6. Averages of the numbers of dead tillers (DTs), live tillers (LTs), and total tillers (TTs) for the different treatments at the end of the deferral period.

\begin{tabular}{cccc}
\hline Treatment & DT (tillers $\left./ \mathbf{m}^{\mathbf{2}}\right)$ & LT $\left(\right.$ tillers $\left./ \mathbf{m}^{\mathbf{2}}\right)$ & TT $\left(\right.$ tillers $\left./ \mathbf{m}^{\mathbf{2}}\right)$ \\
\hline B & $374 \mathrm{~A}$ & $1046 \mathrm{~A}$ & $1420 \mathrm{~A}$ \\
BC & $150 \mathrm{~B}$ & $819 \mathrm{~B}$ & $969 \mathrm{~B}$ \\
B50 & $281 \mathrm{AB}$ & $1224 \mathrm{~A}$ & $1506 \mathrm{~A}$ \\
B100 & $383 \mathrm{~A}$ & $1157 \mathrm{~A}$ & $1539 \mathrm{~A}$ \\
\hline Mean standard error & 33.47 & 36.01 & 55.96
\end{tabular}

Means followed by at least the same letter in the column do not differ at the level of a $5 \%$ probability by the Tukey's test. Abbreviations: B, signal grass which was not fertilized with nitrogen (control); BC, signal grass intercropped with calopo; B50, signal grass fertilized with a dose of $50 \mathrm{~kg} \mathrm{ha}^{-1} \mathrm{~N}$; B100, signal grass fertilized with a dose of $100 \mathrm{~kg} \mathrm{ha}^{-1} \mathrm{~N}$.

In the samples collected via simulated grazing, it was found that the $\mathrm{L} / \mathrm{S}(p=0.0042)$ and the percentages of L $(p=0.0013), \mathrm{S}(p=0.0355)$ and $\mathrm{DE}(p=0.0084)$ were affected by the interaction between treatment and experimental year (Table 7). When comparing treatments within years, in 2017, it was found that the BC treatment resulted in the higher $\mathrm{L} / \mathrm{S}$ and $\% \mathrm{~L}$ values and lower values of $\% \mathrm{~S}$ and $\% \mathrm{DE}$ compared with the other treatments. In 2018, the averages were similar between the different treatments for signal grass. When comparing the years within each treatment, there was a higher $\mathrm{L} / \mathrm{S}$ ratio and a higher $\% \mathrm{~L}$ value and the lower values of \%S and \%DE in 2017 than in 2018 for the BC treatment (Table 7).

The proportions of calopo in the samples collected via direct cutting at the end of the deferral period in the intercropped pasture were $3.0 \%$ and $9.5 \%$ with regard to TDM in 2017 and 2018, respectively. The chemical composition of the calopo was also only evaluated in the samples via direct cutting, which was used to verify the DM contents of $15.9 \%$ and $26.5 \%$ in 2017 and 2018, respectively, the CP contents of $17.3 \%$ and $13.2 \%$ in 2017 and 2018, respectively, and the NDFap contents of $48.6 \%$ and $54.2 \%$ in 2017 and 2018, respectively.

The chemical composition of the signal grass pastures at the end of the deferral period was evaluated in the samples collected via direct cutting and those obtained via simulated grazing. The CP contents in the samples that were directly cut differed $(p=0.0001)$ only among treatments (Figure 2), verifying that the B treatment presented a lower $\mathrm{CP}$ content compared with those of other treatments. However, the CP contents of the samples collected via simulated grazing were affected $(p=0.0007)$ by the interaction between treatment and experimental year, with a higher $\mathrm{CP}$ content $(p<0.05)$ found for the BC treatment compared with those of other treatments in 2017. However, in 2018, the means were similar among all treatments. When comparing years within treatments, the highest CP content in 2017 was found for the $\mathrm{BC}$ treatment. 
Table 7. Averages of the leaf blade/stem (L/S) ratios and percentages of leaf blade (L), stem, and dead material, via simulated grazing, for different treatments and experimental years at the end of the deferral period.

\begin{tabular}{|c|c|c|c|}
\hline Treatment & 2017 & 2018 & Mean Standard Error \\
\hline \multicolumn{4}{|c|}{ L/S } \\
\hline $\mathrm{B}$ & $1.24 \mathrm{Ba}$ & $1.47 \mathrm{Aa}$ & \multirow{4}{*}{0.08} \\
\hline $\mathrm{BC}$ & 2.20Aa & $1.16 \mathrm{Ab}$ & \\
\hline $\mathrm{B} 50$ & $1.09 \mathrm{Ba}$ & $1.42 \mathrm{Aa}$ & \\
\hline B100 & $1.23 \mathrm{Ba}$ & $1.10 \mathrm{Aa}$ & \\
\hline \multicolumn{4}{|c|}{ L (\%) } \\
\hline $\mathrm{B}$ & $51.81 \mathrm{Ba}$ & $54.79 \mathrm{Aa}$ & \multirow{4}{*}{1.31} \\
\hline $\mathrm{BC}$ & 67.27Aa & $49.95 \mathrm{Ab}$ & \\
\hline B50 & $48.98 \mathrm{Ba}$ & $56.31 \mathrm{Aa}$ & \\
\hline B100 & $52.33 \mathrm{Ba}$ & $50.45 \mathrm{Aa}$ & \\
\hline \multicolumn{4}{|c|}{ S (\%) } \\
\hline $\mathrm{B}$ & $42.26 \mathrm{ABa}$ & $40.00 \mathrm{Aa}$ & \\
\hline $\mathrm{BC}$ & $31.61 \mathrm{Bb}$ & $44.34 \mathrm{Aa}$ & 1.22 \\
\hline B50 & $45.25 \mathrm{Aa}$ & $40.42 \mathrm{Aa}$ & \\
\hline B100 & $43.48 \mathrm{Aa}$ & 46.18Aa & \\
\hline \multicolumn{4}{|c|}{ DE (\%) } \\
\hline $\mathrm{B}$ & $5.92 \mathrm{Aa}$ & 5.19Aa & \multirow{4}{*}{0.41} \\
\hline $\mathrm{BC}$ & $1.10 \mathrm{Bb}$ & 5.70Aa & \\
\hline B50 & $5.76 \mathrm{Aa}$ & 3.25Aa & \\
\hline B100 & 4.18ABa & 3.36Aa & \\
\hline
\end{tabular}

Means followed by at least one capital letter in the column and lower case in the line, for each variable, do not differ at the level of a 5\% probability by the Tukey's test. Abbreviations: B, signal grass which was not fertilized with nitrogen (control); BC, signal grass intercropped with calopo; B50, signal grass fertilized with a dose of $50 \mathrm{~kg} \mathrm{ha}^{-1} \mathrm{~N}$; B100 = signal grass fertilized with a dose of $100 \mathrm{~kg} \mathrm{ha}^{-1} \mathrm{~N}$.

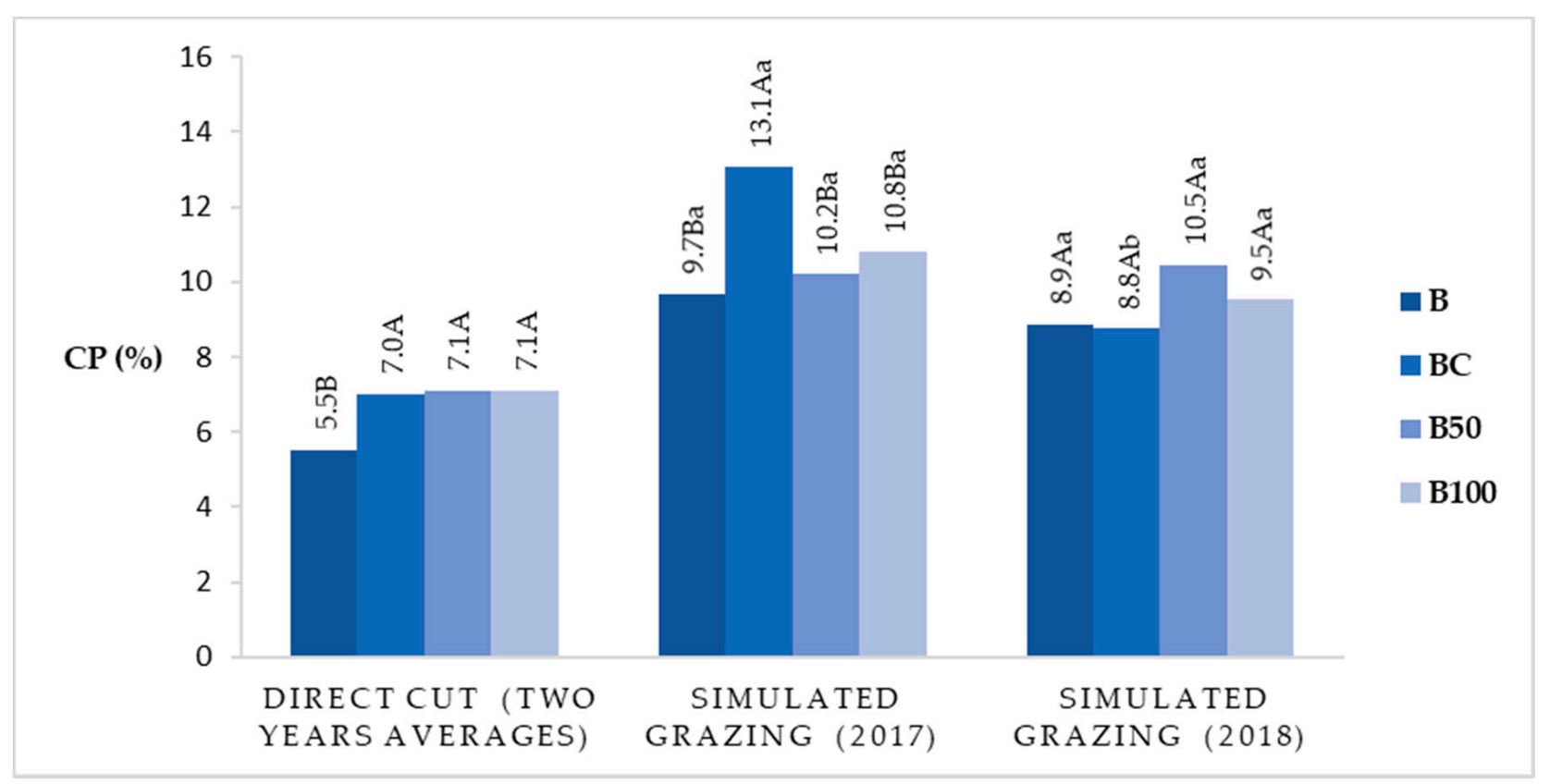

Figure 2. Average values of crude protein (CP) content in signal grass pastures, via direct cutting (among treatments) and via simulated grazing samples (interaction between treatments and years), at the end of the deferral period. Means followed by at least one capital letter (compares treatments) and one lower case (compares years) do not differ at the level of a $5 \%$ probability by the Tukey's test. Abbreviations: B, signal grass which was not fertilized with nitrogen (control); BC, signal grass intercropped with calopo; B50, signal grass fertilized with a dose of $50 \mathrm{~kg} \mathrm{ha}^{-1} \mathrm{~N}$; B100, signal grass fertilized with a dose of $100 \mathrm{~kg} \mathrm{ha}^{-1} \mathrm{~N}$. 
The NDFap content, as determined from the samples obtained via direct cutting, was not affected $(p>0.05)$ by any factors and presented an overall average of $66.5 \%$. Only year affected the NDFap contents of the samples obtained via simulated grazing $(p=0.0012)$, in addition to the $\% \mathrm{DM}$ of samples obtained via direct cutting $(p=0.0001)$ and those obtained via simulated grazing $(p=0.0001$; Table 8$)$. Lower levels of NDFap in the samples obtained via simulated grazing and higher levels of DM in samples obtained by both simulated grazing and direct cutting were observed in 2018 than in 2017 (Table 8).

Table 8. Averages of the neutral detergent fiber corrected for ash and protein (NDFap), in samples from simulated grazing and percentages of dry matter (DM), via direct cutting and simulated grazing, at the end of the deferral period in two experimental years.

\begin{tabular}{cccc}
\hline Year & $\begin{array}{c}\text { NDFap (\%) } \\
\text { (Simulated Grazing) }\end{array}$ & $\begin{array}{c}\text { DM (\%) } \\
\text { (Direct Cutting) }\end{array}$ & $\begin{array}{c}\text { DM (\%) } \\
\text { (Simulated Grazing) }\end{array}$ \\
\hline 2017 & $60.9 \mathrm{~A}$ & $26.9 \mathrm{~B}$ & $27.9 \mathrm{~B}$ \\
2018 & $57.9 \mathrm{~B}$ & $32.4 \mathrm{~A}$ & $33.6 \mathrm{~A}$ \\
Mean standard error & 0.52 & 0.70 & 0.82 \\
\hline
\end{tabular}

Means followed by at least the same letter in the column do not differ at the level of a $5 \%$ probability by the $\mathrm{F}$ test; 2017: deferral period of 98 days, starting from 03/07/2017; 2018: deferral period of 70 days, starting from $03 / 07 / 2018$.

\section{Discussion}

The highest SH and FI (Table 2) at the end of the deferral period for the BC treatment did not differ from those of the treatments that received nitrogen doses, which may be explained by the greater availability of nitrogen in the soil [11], as well as by the quantity and quality of incident light in the forage canopy. According to [20], in intercropped pastures, the proximity of different plants impairs the quantity and quality of light that penetrates the forage canopy, in which the competition between grasses and legumes can result in stalk elongation and increased plant tipping, as was observed in the present study (Tables 2 and 4).

The deferment of a signal grass pasture generally results in an FI greater than 1.0 because of its decumbent growth form [5]. A high FI reflects prostrate growth in a pasture, while values close to one indicate that the pasture grows vertically [21]. In the present study, the FI ranged from 1.51 (control) to 2.07 (consortium), which may be attributed to the thin and flexible stems of signal grass, which promote falling during growth. Among the management strategies that could be used to improve the values of the FI in deferment pastures to reduce the possible forage losses associated with falling, the implementation of shorter deferral periods, lower pasture heights at the start of the deferral period, and reduced nitrogen doses applied at the beginning of the deferral period stand out [22].

As the GDM consists of the sum of the masses of $L$ and $S$, greater GDM values were observed for the BC treatment compared with those for the B treatment in 2017, as the intercropped pasture presented approximately $50 \%$ S while that of the control was $38 \%$ (Table 4). The GDM value for the intercropped pasture was lower in 2018 than in 2017, which may be attributed to a reduction in SDM. In 2018, the highest rainfall during the study period was recorded, but only the B and B100 treatments responded with high GDM values (Table 3 ).

The greater FA for the $\mathrm{BC}$ treatment compared with that for the $\mathrm{B}$ treatment during the first year (Table 3) was probably the result of a greater availability of nitrogen in the soil due to the $\mathrm{N}$ fixation carried out by the legume; however, the amount of FA did not differ between treatments with a nitrogen fertilizer. In the second year, the FAs were similar among the treatments, which may be due to the greater amount of rainfall recorded during that period, as has already been reported. According to [23], higher pastures may reduce FA due to greater leaf senescence, a fact that was not observed in the present study. The intercropped pasture had a lower proportion of DE than the other treatments.

According to [24], the GDM/DEM ratio is important, because it allows for the balance between the masses of living and dead plant tissue in a pasture to be determined. In our 
study, the intercropped pasture had the highest GDM/DEM ratio, without a difference from that for the B50 treatment (Table 4). This finding may favor animal performance, as it is a characteristic of pastures which is more favorable for consumption. However, it should be noted that under deferred pasture conditions, the senescence of plant tissues is generally more accentuated due to the extensive deferral period that is normally adopted to guarantee a reasonable forage stock for the winter period [24].

The highest percentage of $S$ for the BC treatment, which did not differ from that for the B50 treatment, at the end of the deferral period (Table 4) in the samples obtained via direct cutting may be attributed to competition for light between plants, which favors stem elongation [21]. The highest percentages of DE for the B and B100 treatments, which differed from those for the B50 treatment (Table 7), may have been due to the high abundance of DT in these treatments (Table 6).

The intercropped pasture at the end of the deferral period showed lower VT abundance compared with that for the B100 treatment in the first year, and this abundance did not increase during the second year, which was also observed for the B100 treatment (Table 5). In 2018, all treatments had larger VT populations than those of the intercropped pasture. According to [25], nitrogen fertilization is related to improved soil fertility, which promotes a significant increase in the flow of tissues from forage plants, including a greater appearance of tillers. In a study in which signal grass was deferred for 95 days, an increase in the abundance of VTs $\left(744 \mathrm{~m}^{-2}\right.$ to $\left.1.320 \mathrm{~m}^{-2}\right)$ was observed, as the $\mathrm{N}$ dose increased $\left(0 \mathrm{~kg} \mathrm{ha}^{-1}, 50 \mathrm{~kg} \mathrm{ha}^{-1}\right.$, and $\left.100 \mathrm{~kg} \mathrm{ha}^{-1}\right)$ [26]. However, in our study, the responses were not consistent for this characteristic, reflecting a similar abundance of VTs among the signal grass pastured (either fertilized or not (control)). In addition, it was observed that there was no difference in the number of DTs, LTs, and TTs in the fertilized pastures, while the $\mathrm{BC}$ treatment presented lower values for these variables (Table 6). The lower densities of LTs and TTs for the BC treatment may be attributed to its greater height (Table 2), with a subsequent compensation in the density/size ratio of tillers [27].

At the end of the deferral period, in the samples obtained by simulated grazing, the values of the L/S ratio and \%L were higher, while the percentages of $\% \mathrm{~S}$ and \%DE were lower (Table 7) than those of the samples obtained via direct cutting, regardless of either the treatment or year. These results demonstrated that the characteristics of the pasture did not represent the characteristics of the forage ingested by the animals due to selective grazing behavior. Animals prefer certain parts of plants, and thus, the composition of their diet often differs from that of the pasture [28].

With regard to the chemical composition of the samples obtained by direct cutting, the highest levels of CP, which were registered for the BC, B50, and B100 treatments (Figure 2), were probably the result of a greater availability of nitrogen in the soil and consequently high nitrogen content in the forage. In signal grass samples, which underwent three different periods of deferment (73 days, 95 days, and 116 days) and four doses of nitrogen $\left(0 \mathrm{~kg} \mathrm{ha}^{-1}, 40 \mathrm{~kg} \mathrm{ha}^{-1}, 80 \mathrm{~kg} \mathrm{ha}^{-1}\right.$, and $\left.120 \mathrm{~kg} \mathrm{ha}^{-1}\right)$ in an experiment that was previously conducted in the same experimental area, CP levels ranging from $2.86 \%$ to $5.97 \%$ were found [22], which are values lower than those found in the present study.

The highest $\mathrm{CP}$ content for the BC treatment in the samples collected via simulated grazing in 2017 (Figure 2) may be attributed to the greater percentage of leaves of signal grass (Table 7), morphological component with the highest nitrogen content, and due to the calopo source. However, calopo was not obtained from the samples collected via simulated grazing, possibly because it was only performed in the initial three grazing days when the heifers were still acclimating to grazing and selected more grass than legumes. In addition, it has been recognized that calopo has low acceptability, which limits its consumption by grazing animals [29].

In a study carried out by [3], a CP content of $8.1 \%$ was found in the samples obtained through simulated grazing in a signal grass monoculture fertilized with a dose of $50 \mathrm{~kg} \mathrm{ha}^{-1}$ $\mathrm{N}$ and 126 days of deferral. In the present study, higher $\mathrm{CP}$ levels were found, ranging from $8.7 \%$ (BC treatment in 2018) to 13.1\% (BC treatment in 2017; Figure 2). The higher CP 
levels found in samples collected via simulated grazing compared with those obtained via direct cutting may be attributable to the higher proportion of $L$ than that of $S$ in the upper grazing horizon of the canopy [30], with the leaf fraction being most selected by grazing animals [31].

The simulated grazing technique is important for adjusting possible nutritional imbalances in the available forage [32], as samples of tropical pastures obtained near the ground level underestimate the nutritional value of the pasture, which will be harvested by grazing animals [30]. However, if we assume that the forage obtained by simulated grazing is similar to that of the forage selected by animals, it can be inferred that the nitrogen content in the present study was not a limiting factor for dry matter intake by grazing animals, considering that the critical level of $\mathrm{CP}$ in the diet was estimated to be between $6 \%$ and $7 \%$ [33].

The higher NDFap content in the samples obtained via simulated grazing in 2017 compared with that in 2018 (Table 8) may be attributed to the longer deferral period of the pasture in the first year, as a greater deposition of the NDF fraction in plants with longer periods of growth has been reported [34]. Reference [3] recorded an average NDFap content of $69.2 \%$ in samples that were obtained via the simulated grazing of signal grass that was deferred for 126 days, which exceeds the values obtained from the samples obtained via simulated grazing and direct cutting in the present study.

In deferred pastures, it is known that the use of nitrogen fertilization improves the accumulation, structural characteristics, and chemical composition of forage, but the advance we achieved in this study is of great importance for agriculture, as we were able to confirm our hypothesis that the use of mixed signal grass-calopo pastures provides similar benefits to those of monoculture pastures fertilized with nitrogen.

The intercropping of signal grass and calopo may be recommended for deferment to guarantee the accumulation of forage, structural characteristics, and CP content equivalent to those of fertilized pastures. In addition, there are the benefits of biological nitrogen fixation and the lower cost of intercropping.

Author Contributions: Conceptualization, C.S.C., K.G.R., O.G.P., and D.M.d.F.; methodology, C.S.C., K.G.R., O.G.P., and D.M.d.F.; software, C.S.C. and P.R.C.; validation, C.S.C. and K.G.R.; formal analyses, C.S.C.; investigation, C.S.C. and K.G.R., resources, K.G.R. and O.G.P.; dados curation, C.S.C. and K.G.R.; writing—original draft preparation, C.S.C.; writing—review and editing, C.S.C., K.G.R., O.G.P., D.M.d.F., P.R.C., and C.A.d.M.G.; project administration, K.G.R.; supervision, K.G.R. All authors have read and agreed to the published version of the manuscript.

Funding: This research received funding from the Conselho Nacional de Desenvolvimento Científico e Tecnológico (CNPq) for the scholarship to the first author and from the Coordenação de Aperfeiçoamento de Pessoal de Nível Superior (CAPES).

Institutional Review Board Statement: The study was conducted according to the guidelines of the Declaration of Helsinki, and approved by the Ethics Committee of UNIVERSIDADE FEDERAL DE VIÇOSA (protocol code 020/2018).

Informed Consent Statement: Not applicable.

Data Availability Statement: Not applicable.

Acknowledgments: The authors gratefully acknowledge the Coordenação de Aperfeiçoamento de Pessoal de Nível Superior (CAPES) and the Conselho Nacional de Desenvolvimento Científico e Tecnológico (CNPq). K.G.R. (309784/2019-0), O.G.P., P.R.C., and C.A.M.G. are CNPq research fellowship recipients.

Conflicts of Interest: The authors declare that there is no conflict of interest. 


\section{References}

1. Allen, V.G.; Batello, C.; Berretta, E.J.; Hodgson, J.; Kothmann, M.; Li, X.; McIvor, J.; Milne, J.; Morris, C.; Peeters, A.; et al. An international terminology for grazing lands and grazing animals. Grass Forage Sci. 2011, 66, 2-28. [CrossRef]

2. de Lana Sousa, B.M.; Santos, M.E.R.; de Amorim, P.L.; da Silveira, M.C.T.; de Oliveira Rocha, G.; de Carvalho, A.N. Effect of nitrogen fertilization on structure and tillering dynamics of Piata palisade grass during the deferment period. Semin. Ciências Agrárias 2019, 40, 249-258. [CrossRef]

3. Silva, C.S.; Montagner, D.B.; Euclides, V.P.B.; Queiroz, C.D.A.; Andrade, R.A.S. Steer performance on deferred pastures of Brachiaria brizantha and Brachiaria decumbens. Ciência Rural 2016, 46, 1998-2004. [CrossRef]

4. Prado, D.A.; Zanine, A.D.M.; Ferreira, D.D.J.; Rodrigues, R.C.; Santos, E.M.; Pinho, R.M.A.; Portela, Y.P.N. Morphogenetic and structural characteristics, yield and chemical composition of signal grass under deferred grazing. Biol. Rhythm Res. 2019, 50, 1-8. [CrossRef]

5. Silva, A.A.S.; Fonseca, D.M.D.; Santos, M.E.R.; Sousa, B.M.D.L.; Gomes, V.M.; Cantarutti, R.B. Initial height and nitrogen fertilization on deferred signal grass. Biosci. J. 2015, 31, 1671-1681. [CrossRef]

6. Amorim, P.L.; Fonseca, D.M.; Santos, M.E.R.; Pimentel, R.M.; Rodrigues, J.P.P.; Chizzotti, F.H.M.; Vitor, C.G. Beef cattle performance on signal grass pastures deferred and fertilized with nitrogen. Arq. Bras. De Med. Veterinária E Zootec. 2019, 71, 1395-1402. [CrossRef]

7. Pimentel, D.; Williamson, S.; Alexander, C.E.; Gonzalez-Pagan, O.; Kontak, C.; Mulkey, S.E. Reducing energy inputs in the US food system. Hum. Ecol. 2008, 36, 459-471. [CrossRef]

8. Li, Q.; Yu, P.; Li, G.; Zhou, D. Grass-legume ratio can change soil carbon and nitrogen storage in a temperate steppe grassland. Soil Tillage Res. 2016, 157, 23-31. [CrossRef]

9. Lüscher, A.; Mueller-Harvey, I.; Soussana, J.F.; Rees, R.M.; Peyraud, J.L. Potential of legume-based grassland-livestock systems in Europe: A review. Grass Forage Sci. 2014, 69, 206-228. [CrossRef] [PubMed]

10. Ferreira, T.C.; Aguilar, J.V.; Souza, L.A.; Justino, G.C.; Aguiar, L.F.; Camargos, L.S. pH effects on nodulation and biological nitrogen fixation in Calopogonium mucunoides. Braz. J. Bot. 2016, 39, 1015-1020. [CrossRef]

11. Cadisch, G.; Schunke, R.M.; Giller, K.E. Nitrogen cycling in a pure grass pasture and a grass-legume mixture on a red latosol in Brazil. Trop. Grassl. 1994, 28, 43.

12. dos Santos, H.G.; Jacomine, P.K.T.; dos Anjos, L.H.C.; de Oliveira, V.A.; de Oliveira, J.B.; Lumbreras, J.F.; Coelho, M.R.; Cunha T.J.F. Sistema Brasileiro de Classificação de Solos; Embrapa: Brasília, Brazil, 2018.

13. Cantarutti, R.B.; Martins, C.E.; Carvalho, M.M.; Fonseca, D.M.; Arruda, M.L.; Vilela, H.; Oliveira, F.T.T. Pastagens. In 5 ${ }^{a}$ APROXIMAÇÃO. Recomendações para o uso de Corretivos e Fertilizantes em Minas Gerais; Comissão de Fertilizantes do Solo do Estado de Minas Gerais: Viçosa, MG, USA, 1999; 332p.

14. AOAC International. Official Methods of Analysis. The Association of Official Analytical Chemists, 18th ed.; AOAC International: Arlington, VI, USA, 2005.

15. Mertens, D.R. Gravimetric determination of amylase-treated neutral detergent fiber in feeds with refluxing in beakers or crucibles: Collaborative study. J. AOAC Int. 2002, 85, 1217-1240.

16. Licitra, G.; Hernandez, T.M.; Van Soest, P.J. Standardization of procedures for nitrogen fractionation of ruminant feeds. Anim. Feed. Sci. Technol. 1996, 57, 347-358. [CrossRef]

17. Santos, M.E.R.; Fonseca, D.M.D.; Euclides, V.P.B.; Nascimento Júnior, D.D.; Queiroz, A.C.D.; Ribeiro Júnior, J.I. Características estruturais e índice de tombamento de Brachiaria decumbens cv. Basilisk em pastagens diferidas. Rev. Bras. Zootec. 2009, 38, 626-634. [CrossRef]

18. Sollenberger, L.E.; Cherney, D.J.R. Evaluating forage production and quality. In Forages: The Science of Grassland Agriculture; Barnes, R.F., Miller, D.A., Nelson, C.J., Eds.; Iowa State University Press: Ames, IA, USA, 1995; Volume 2, pp. $97-110$.

19. Sistemas para Análises Estatísticas e Genética; Versão 5.0; Fundação Artur Bernardes: Viçosa, Brazil, 2003.

20. Ballaré, C.L.; Scopel, A.L.; Sánchez, R.A. On the opportunity cost of the photosynthate invested in stem elongation reactions mediated by phytochrome. Oecologia 1990, 86, 561-567. [CrossRef]

21. Santos, M.E.R.; Fonseca, D.M.D.; Gomes, V.M.; Pimentel, R.M.; Albino, R.L.; Silva, S.P.D. Signal grass structure at different sites of the same pasture under three grazing intensities. Acta Sci. Anim. Sci. 2013, 35, 73-78. [CrossRef]

22. Santos, M.E.R.; Fonseca, D.M.D.; Oliveira, I.M.D.; Casagrande, D.R.; Balbino, E.M.; Freitas, F.P. Correlações entre número de perfilhos, índice de tombamento, massa dos componentes morfológicos e valor nutritivo da forragem em pastos diferidos de capim-braquiária. Rev. Bras. Zootec. 2010, 39, 487-493. [CrossRef]

23. Santos, M.E.R.; Fonseca, D.M.D.; Gomes, V.M. Forage accumulation in signal grass under continuous grazing with single or variable height during the seasons of the year. Rev. Bras. Zootec. 2013, 42, 312-318. [CrossRef]

24. Santos, M.E.R.; Da Fonseca, D.M.; Gomes, V.M.; Balbino, E.M.; Magalhães, M.A. Estrutura do capim-braquiária durante o diferimento da pastagem. Anim. Sci. 2010, 32, 139-145. [CrossRef]

25. Sousa, B.M.D.L.; Vilela, H.H.; Santos, A.L.; Santos, M.E.R.; Nascimento Júnior, D.D.; Assis, C.Z.D.; Faria, B.D.; Rocha, G.D.O. Piata palisadegrass deferred in the fall: Effects of initial height and nitrogen in the sward structure. Rev. Bras. Zootec. 2012, 41, 1134-1139. [CrossRef]

26. Teixeira, F.A.; Bonomo, P.; Pires, A.J.V.; Silva, F.F.; Abreu Filho, G.; Viana, P.T. Tiller population density in deferred Urochroa decumbens pasture and strategies for nitrogen fertilization. Acta Sci. Anim. Sci. 2013, 35, 79-84. [CrossRef] 
27. Matthew, C.; Lemaire, G.; Hamilton, N.S.; Hernandez-Garay, A. A modified self-thinning equation to describe size/density relationships for defoliated swards. Ann. Bot. 1995, 76, 579-587. [CrossRef]

28. Decruyenaere, V.; Buldgen, A.; Stilmant, D. Factors affecting intake by grazing ruminants and related quantification methods: A review. BASE 2009, 13, 559-573.

29. Carvalho, G.G.P.; Pires, A.J.V. Leguminosas tropicais herbáceas em associação com pastagens. Arch. Zootec. $2008,57,103-113$.

30. Hughes, M.P.; Jennings, P.G.A.; Mlambo, V.; Lallo, C.H. Effect of season and harvesting method on chemical composition, predicted metabolizable energy and in vitro organic matter digestibility of rotationally grazed tropical pastures. J. Anim. Feed. Res. 2012, 1, 405-417.

31. Euclides, V.P.B.; Montagner, D.B.; Barbosa, R.A.; Valle, C.B.D.; Nantes, N.N. Animal performance and sward characteristics of two cultivars of Brachiaria brizantha (BRS Paiaguás and BRS Piatã). Rev. Bras. Zootec. 2016, 45, 85-92. [CrossRef]

32. De Vries, M.W. Estimating forage intake and quality in grazing cattle: A reconsideration of the hand-plucking method. Rangel. Ecol. Manag./J. Range Manag. Arch. 1995, 48, 370-375. [CrossRef]

33. Minson, D.J. Forage in Ruminant Nutrition; Academic Press: San Diego, CA, USA, 1990; 483p.

34. Ansah, T.; Osafo, E.L.K.; Hansen, H.H. Herbage yield and chemical composition of four varieties of Napier (Pennisetum purpureum) grass harvested at three different days after planting. Agric. Biol. J. North Am. 2010, 1, 923-929. [CrossRef] 